\title{
Research Paper: Analysis of Structural Pattern of Road Access Network in Villages Exporting Agricultural Crops (Case Study: Maragheh City)
}

\author{
Saeedeh Farrokhi ${ }^{1}$, Abdolreza Rokneddin Eftekhari ${ }^{*}{ }^{*}$, Mahdi Pourtahari ${ }^{3}$, Jalal Karami ${ }^{4}$
}

1. PhD Candidate, Department of Geography and Rural Planning, Faculty of Humanities, Tarbiat Modarres University, Tehran, Iran.

2. Professor, Department of Geography and Rural Planning, Faculty of Humanities, Tarbiat Modarres University, Tehran, Iran.

3. Associate Professor, Department of Geography and Rural Planning, Faculty of Humanities, Tarbiat Modarres University, Tehran, Iran

4. PhD, Department of Remote Sensing, Faculty of Humanities, Tarbiat Modarres University, Tehran, Iran.

Article info:

Received: 17 July 2019

Accepted: 23 Nov 2019

Keywords:

Network Analysis, Structural Pattern, Access Network, Road, East Azerbaijan
Citation: Farrokhi, S., Eftekhari, A. R., Pourtahari, M., \& Karami, J. (2020). Analysis of Structural Pattern of Road Access Network in Villages Exporting Agricultural Crops (Case Study: Maragheh City). Journal of Sustainable Rural Development, 4(1), 3-22. https://doi.org/10.32598/JSRD.03.02.01

https://doi.org/10.32598/JSRD.03.02.01 


\section{Introduction}

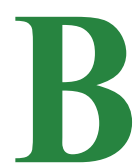

ased on the analysis of texts, a network is a set of relationships. It is a set of nodes and a diagram or outline of the relationships between the nodes. Each person or communication node is connected to one or more other persons. The network emphasizes the fact that each person has communication nodes with other people, each of which is connected to a small, medium, and large number of other people (Oftadeh, 2016: 35). In a network, the nodes represent the points from which the flow starts or the points at which it ends or changes. Branches are also used to connect two nodes and represent a kind of connection between two nodes. In such networks, the branches can represent roads, pipelines, shipping services, and so on. In some other cases, the branches may represent the logical sequence of activities. Communication lines, rail networks, post networks, and pipeline systems are examples of the networks (Asgharpour \& Hashemi, 2005: 21-22). Therefore, the relationship includes a certain part of the network in which one line can connect a point to another point in a certain direction, meaning that there are no parallel lines (Rezvani et al., 2014: 16). Networks can be considered as a set of nodes that represent locations and a set of links that represent communications. They have different structural characteristics in which topological and geometric changes are displayed. The order and connection of nodes and links of a network refer to its topology. Some topological methods of network structure have been developed based on the basic concepts of graph theory, and in a network with a higher level of complexity, geometrical characteristics such as distance, shape, orientation, density, and geometric patterns may be introduced.

Hence, it can be stated that a network has a broad and yet complex meaning. One of the applied concepts of the network is the spatial structure that connects the primary and secondary points through the channels (Ramezani A., M.a, 2015: 283). In fact, one particular type of network is the network that is embedded in real space; for example, networks in which nodes occupy a certain position in two-dimensional or three-dimensional Euclidean space and the edges are real physical relationships. A prominent example is neural networks. Other important examples include communication networks, power networks, transportation through rivers, airports, streets, railways, and the metro. A review of the literature suggests that many studies have focused on identifying network topological characteristics, while less attention has been paid to the spatial aspect. Such topologies of spatial networks are also severely confined to their geographical environment. Some of the main features and spatial constraints in working on spatial networks include: 1- Basic information about the spatial distribution of nodes in the network 2- Degree of nodes in the spatial networks is limited to several edges that can be connected to a single node and these edges are confined by the physical space for communication with them. It is more evident in bidirectional networks, such as street patterns or ant gallery networks. 3- Because of the cost related to the space of the nodes, the nodes are less likely to be linked (S. Boccaletti et al., 2006: 206-205).

Hence, it can be stated that the spatial structure of the network forms the traffic flow in a network. The desired characteristics of the network structure that travelers perceive in their travels, such as clarity, dispersion, and convenience, are important indices of the quality of network design and road transportation planning (Xie \& Levinson, 2007: 336-337). In fact, the long-term advantage of studying and analyzing the spatial pattern and structure of the road network through the intrinsic impact of the network structure on the performance of transport systems, quality of access (cost, time, distance, convenience, etc.), and subsequent impacts on land use have been considered (Xie \& Levinson, 2007: 336-337). In these studies, measurable indices can reveal the structural characteristics of complex networks and can be useful in studying the structural evolution of these networks in a spatial and temporal environment.

Preliminary studies on the analysis of road networks have begun from the 1960s in which geography and transportation researchers focused exclusively on topological criteria through network analysis based on graph theory for limited data and computational power and modeling techniques. After this decade and with greater access to travel demand models, researchers began studying the traffic flows and travel patterns that are affected by the structure of different geometric networks (Vaughan, 1987: 76-80). Communication patterns of roads, especially highways, have been both quantitatively and qualitatively measured in some empirical studies. In recent decades, network studies have shifted from simple topological and geometric features to statistical features at a large scale of complex networks. Some of these studies are used as examples of large-scale transportation networks such as the airline system and the national highway network. The road transportation network includes several arcs of different types (e.g. highways, main roads, secondary roads, and so on) (Blyde, 2010). These networks constitute a building of intercon- 
nected complexes linking a part of the primary points (cities) to secondary points (villages).

Hence, to achieve the desired position, comprehensive use of transportation facilities has great importance. For this purpose, in assessing the accessibility of such points, the whole communication system should be considered rather than a specific route. Therefore, the strategic study of a network, such as analyzing its fabric, structure, and communication characteristics, and the optimal design of the transportation network have economic implications and provide inexpensive transportation facilities (Ramezani A., M.a, 2015: 283). In this regard, studying the spatial pattern of the rural road network, especially in areas with special economic and production status, can be effective in the development of these areas and facilitating access to services, since the way of communication among the villages affects the cost, distance, and time of villagers' access to services related to the activity and transportation of products from the villages. Hence, this study attempts to analyze the network accessibility of roads resulting from relationships between the villages in the form of transportation of agricultural crops to cold stores by using network structural analysis method. In this study, villages and cold stores constitute the network nodes and the rural roads, and the main roads constitute the network edges. Therefore, the present study seeks to answer the question of what the characteristics of the road access pattern of apple crop relationships in villages of Maragheh are and what kind of networking pattern it matches.

\section{Literature Review}

A review of the literature indicated that the roots of network thinking in the social and geographical thought of Grebher are attributed to Simmel (1890). In 1954, Barnes, a member of the Manchester group, used the concept of the social network to analyze relationships that link kinship groups and social classes in a fishing village in Norway. The concept of the network not only helped him to describe the social structure of the village more accurately but also helped him to realize that the concept of the network was more useful than legal concepts for studying such social processes, such as access to jobs and political activities. Then, a group at Harvard University introduced two innovations using mathematics: developing algebraic models of groups by using set theory and multidimensional survey. A multidimensional survey is a mathematical technique that transforms relationships into the social distance to outline them in the social space. These innovations led to efforts to outline the interpersonal relationships and develop micro mod- els to describe their patterns (Rezvani et al., 2014, pp. 22-27). Given what was stated, the study of networks has nowadays developed in all ecological, physical, social, and economic aspects and an active field for research has been provided and some specialized journals have been published in this field. Hence, it can be stated that in the social sciences, two interactive and structural aspects are examined in studying the networks. However, geographical sciences have focused on three aspects of structure, interactions in the form of flows, and performance (Azarbad, 2010: 75-89).

The quality of a network is also measured in different ways: general qualitative criteria including network weight (overall length of all edges in a network), diameter (longest distance between two locations), and dilation (the largest ratio of network distance to Euclidean distance) (David, 1996: 229-238). In this regard, the network structure has attracted much attention to the geography of transportation since the 1950s. In the next decades, developments in complex network theory created a growing body of literature of applications in the transportation system. Therefore, network analysis in geography and programming was revived by the influx of new concepts and methods. Unlike many studies on the analysis of complex networks by physical scientists, studies conducted by geographers have yielded benefits beyond testing the statistical characteristics of the networks and dividing them into small-world or scale-free criteria. The distinct roles of network nodes and communication with traffic flows are the primary interests of geographic research relative to the spatial structure of the transportation network. Criteria for analyzing the general structure of the network at the macro level include degree (density) distribution, mean path length and clustering coefficient, and centrality criteria for the individual nodes at the micro-level including degree, closeness, and betweenness, and eigenvector.

Nodes and links are also ranked according to a particular algorithm and the mentioned criteria that respectively represent the situational advantages of one node, including direct connection to other nodes, availability to other nodes, and a mediator between other nodes and these centralities have important implications in shaping the spatial pattern of economic activities (J. Wang et al., 2011, 715; Snarskii et al., 2016: 266-273). It seems that the concept of networks has become a new paradigm that has enabled us to describe a variety of systems and their dynamic behaviors. Therefore, network theory is successfully applied in many different systems, ranging from biological processes to infrastructure and communications and social relationships. Thus, an object, a 
set of topics, a process, a relational matrix, etc. can all be represented in the form of nodes and links, called graphs or networks (Bono \& Gutiérrez, 2011: 1443-1445). In other words, network theory and its types are applied in many fields such as information theory, distribution systems, transportation systems, inventory control, and production planning, and so on. Communication lines, rail networks, pipeline systems, road networks, shipping lines, and airlines are examples of these networks. In fact, many of the issues that are formulated as linear programming can also be in the form of a network. Visual representation of network patterns also facilitates their compression (Sadeghi \& Safari, 2013: 75).

Within this framework, based on the network theory, one focuses on the structure of actors' relationships rather than on actors and their characteristics in analyzing. Thus, within the social aspect framework, links, and relationships, which are the main focus of the network perspective, are considered as social capital. From a network perspective, the root of social capital goes back to communications and social networks. Based on this perspective, relationships among various components and elements of the phenomena are considered. Network theory argues that there are interactive networks between components of society, both at the micro and macro levels (Oftadeh, 2016: 59-60).

In this regard, the network patterns are derived from laboratory tests, in which the structure of groupings can be manipulated by the tester. Figure 2 illustrates the five common types of networks. The major difference among the networks is their degree of centralization or decentralization. The importance of a network depends on its potential effects on variables such as speed, accuracy, leadership spirit, stability, organization, and flexibility. The effectiveness of a network depends on situational factors, for example, centralized networks are effective for simple relationships (demand) and decentralized networks are effective for complex relationships (Sadeghlo, 2012). The characteristics and strengths and weaknesses of each of the network patterns have been presented in Table 1 .

Given what was stated above, at present, network pattern analysis has been upgraded from a proposed metaphor to a paradigm analysis approach. It includes theoretical propositions, analytical software, and its researchers. The unit of analysis in the analysis of the network pattern is the relationship. Network researchers, including Wasserman and Fast, classify the levels of network analysis as follows:

Action level: It deals with social entities such as individuals, organizations, cities, and so on.

Dual level: It consists of two actors and possible links between them.

Triple level: It consists of three actors and possible links among them.

The subset level: It consists of subgroups of the actors and all the links among them.

Table 1. Characteristics and strengths and weaknesses of each of the network patterns

\begin{tabular}{|c|c|c|c|}
\hline $\begin{array}{c}\text { Network } \\
\text { pattern }\end{array}$ & Characteristics & Strength & Weakness \\
\hline 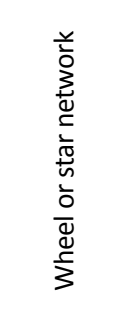 & $\begin{array}{c}\text { - Two-level hierarchical network, the most centralized and structured } \\
\text { type of network } \\
\text { Relationship of each member with only one member } \\
\text { The degree of node A (primary node) is higher than the rest of the } \\
\text { nodes. } \\
\text { Equality of the eigenvector centrality of all nodes with each other } \\
\text { except with node } A\end{array}$ & $\begin{array}{l}\text {-Easy access methods } \\
\text {-Central control and trouble- } \\
\text { shooting are appropriate } \\
\text { to the type of relationship } \\
\text { based on the individual } \\
\text { (each of the nodes individu- } \\
\text { ally has a relationship with } \\
\text { the center with no complete } \\
\text { presence of peer-to-peer } \\
\text { communication). }\end{array}$ & $\begin{array}{l}\text { - -Dependency } \\
\text { to central point } \\
\text { dependency } \\
\text { - The difficulty of } \\
\text { development } \\
\text { - Extended length } \\
\text { of network }\end{array}$ \\
\hline 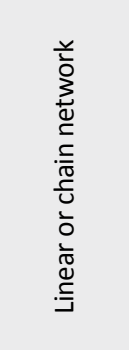 & $\begin{array}{l}\text { - Ranked second in terms of degree of concentration. } \\
\text { - In this pattern, only two nodes have a relationship with each other, } \\
\text { each of them having only one node or member. } \\
\text { - The degree of all nodes except for the first and last nodes is the } \\
\text { same. } \\
\text { - The centrality of proximity and the intermediate centrality of the } \\
\text { middle node is greater than the rest of the nodes. } \\
\text { - The degree of all nodes except for the first and last nodes is the } \\
\text { same. } \\
\text { - The closeness centrality of proximity and the betweenness central- } \\
\text { ity of the middle node is greater than those of the rest of the nodes. }\end{array}$ & $\begin{array}{c}\text { - Reliable pattern in very } \\
\text { small networks and ease of } \\
\text { use and understanding; } \\
\text {-Need for fewer road lines to } \\
\text { connect the nodes to each } \\
\text { other; } \\
\text {-Lower construction cost; } \\
\text { - Fewer problems to expand- } \\
\text { ing }\end{array}$ & $\begin{array}{l}\text { - Traffic problems } \\
\text { on crowded } \\
\text { routes due to slow } \\
\text { traffic flow; } \\
\text { - Any connection } \\
\text { of two routes to } \\
\text { each other weak- } \\
\text { ens the traffic } \\
\text { flow. }\end{array}$ \\
\hline
\end{tabular}


Table 1. Characteristics and strengths and weaknesses of each of the network patterns

\begin{tabular}{|c|c|c|c|}
\hline $\begin{array}{l}\text { Network pat- } \\
\text { tern }\end{array}$ & Characteristics & Strength & Weakness \\
\hline 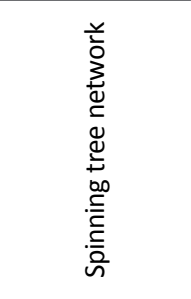 & $\begin{array}{c}\text { - From each node, there is only one route } \\
\text { to the root. } \\
\text { - The connections of a graph are non-circu- } \\
\text { lar and include all nodes of the reference } \\
\text { graph. } \\
\text { - Only one line in each node can leave it (ex- } \\
\text { iting the manhole), except in the root. } \\
\text {-The spinning tree network is a hybrid } \\
\text { topology. }\end{array}$ & $\begin{array}{l}\text { - The possibility of access to the } \\
\text { central part of the network with } \\
\text { presence of an additional pole } \\
\text { (centers) on the network; } \\
\text { - The spinning tree network is less } \\
\text { expensive than a fully connected } \\
\text { (grid) network. } \\
\text {-It can detect the shortcomings } \\
\text { and deficiencies in the network. }\end{array}$ & $\begin{array}{l}\text { Prolonged and expensive pro- } \\
\text { cess of construction }\end{array}$ \\
\hline 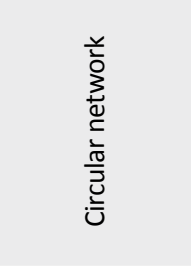 & $\begin{array}{c}\text { - There are a few nodes and links. } \\
\text {-The item, information or population flows } \\
\text { around the loop from one node to another } \\
\text { node. } \\
\text { In this type of network, defective nodes can } \\
\text { be removed from loop. }\end{array}$ & The ease of use of the network & $\begin{array}{l}\text { A failure in the loop will result in } \\
\text { failure in the entire network; } \\
\text { - Disruption in the entire net- } \\
\text { work by removing a node from } \\
\text { the network. } \\
\text { Disconnection of the node with } \\
\text { the network in the case of loss } \\
\text { of power. }\end{array}$ \\
\hline 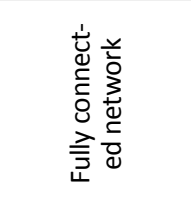 & $\begin{array}{l}\text { Nodes are connected through multiple } \\
\text { routes, and each node has more options } \\
\text { than one route to connect to other nodes. } \\
\text { - Despite the maximum redundancy, if } \\
\text { one node fails, the network traffic can be } \\
\text { redirected to the other node. }\end{array}$ & $\begin{array}{l}\text { Connecting all network nodes } \\
\text { together }\end{array}$ & $\begin{array}{l}\text {-High construction cost due to } \\
\text { long road required to construct } \\
\text { this network pattern } \\
\text { - Need for a large number of } \\
\text { input / output locations }\end{array}$ \\
\hline
\end{tabular}

Source: Pandya, 2013: 21-27; Lunenburg, 2011: p. 153

Network level: It includes certain sets of actors and the relationships defined among them (Ramezani, 2013: 18-20).

In other words, in a typical type of network pattern study, each member of the organization faces a list of other members of the organization. Respondents are asked to identify the individuals or nodes with which they have a relationship and identify the ways of these interactions. Finally, this report data collected by network software are displayed as a visual representation of all network nodes and relationships. Researchers have proposed several criteria for quantifying the fundamental differences in network structure. Some of the used criteria are the degree centrality of the node (the range in which actors send or receive direct relationships), the betweenness centrality (the range in which actors have relationships with other actors that are not directly related to each other), closeness centrality (the range in which actors are directly or indirectly related to other actors in the network), interrelationships (the range in which actors have a mutual relationship), and transferability (the range in which the actors that are connected to one actor have also relationships with other actors (Katz et al., 2004: 314). Within this framework, several domestic and foreign studies have been conducted on the network structure, some of which are listed in Table 2.
In this framework, the studied criteria of network pattern are listed in Table 3.

Given what was stated, the values of the structural indices in each of the network patterns are presented in Table 4.

Density: The ratio of the number of links in the network to the number of possible links indicates the network density index and always takes a value between zero and one. Density measures the degree of coherence among the nodes. If it is closer to one, the coherence of the network will be higher, and if it is closer to zero, the coherence of the network will be lower (Garaei \& Siamaki, 2016). The average degree of a network is the number of neighbors (directly connected nodes) that a node has in the network (J. Wang et al., 2011: 720). In this framework, for the structural pattern of the transportation network, weighted quantities such as traffic flows, cost, travel time, and distance have recently been used in examining the heterogeneity in the density of connection patterns, assessed by the weight of the edges, among the pairs of nodes. The density of a Si node is defined as follows:

$$
\mathrm{S}_{\mathrm{v}} \sum_{\mathrm{j} \subset \mathrm{N}(\mathrm{v})} \mathrm{W}_{\mathrm{vj}}
$$


Table 2. Domestic and foreign studies conducted on the network structure

\begin{tabular}{|c|c|c|}
\hline Results & Title of paper & Authors \\
\hline $\begin{array}{l}\text { The results show that by applying the network analysis method, it is possible to } \\
\text { quickly and easily identify the functional relationships among human settlements. }\end{array}$ & $\begin{array}{l}\text { Analysis of functional -service } \\
\text { relationships of human settle- } \\
\text { ment using network analysis: } \\
\text { Roniz district }\end{array}$ & $\begin{array}{l}\text { Badri \& Akbar- } \\
\text { ian Ronizi, } \\
2008\end{array}$ \\
\hline $\begin{array}{l}\text { In his study, streets are considered as edges and intersections as network nodes } \\
\text { and structural characteristics such as centrality, proximity, continuity, closeness } \\
\text { and symmetry were studied. They also implemented two graphs of triangular net- } \\
\text { work and tree network. They have been processed topologically and geometrically } \\
\text { (the weight of each edge to its length), and some structural and multi-centrality } \\
\text { (closeness and boundary centrality) indices have been extracted. }\end{array}$ & $\begin{array}{l}\text { A structural analysis of street } \\
\text { networks to determine the } \\
\text { characteristics of urban fabric }\end{array}$ & $\begin{array}{l}\text { Hamaina, } \\
2011\end{array}$ \\
\hline
\end{tabular}

In his study, he used a complex network approach to analyze the structure and spatial pattern of the air freight network in western China. He used the indices of population density and, GDP level of the city, and number of air routes in the city to analyze the air transport network. In this study, population density and economics in eastern China were the major factors of spatial pattern of the air transport network.

Investigating the network structure and centrality of China's airline transportation network nodes : a complex network approach

Jo Wong et al., 2011

Settlement network analysis with emphasis on population flows in the Firouzkooh city in the network structure of Firouzkooh city. The general pattern governing the Firoozkooh settlement network is a seasonal and cyclical pattern of population flows that is considered on summer and winter network patterns at local and regional levels.

Table 3. The study questions in the questionnaire

\section{Interaction criteria}

1- Frequency of communication (number and continuity of interaction),

2- Nature of node (purpose and function of the relationship; types of communication node such as exchanges, commitments, emotions, and power),

3- Multiplicity (frequency of communication, number of concepts combined in a relationship), 4- Symmetry (degree of relationship symmetry, such as if A chooses B, does B choose A?)

5-Node strength (strengths and weaknesses, relative value of time, consequences, severity of the interaction)

B) Network structural criteria

1-Size (number of people or network connections),

2- Density (network relationships, actual link counted relative to total links)

3-Distance or estimate (number of links between two nodes in the network)

4- Centrality (the effect of groups and subgroups on the network),

5- Cluster (separation of groups into subgroups and categories of network)

6- Network roles:

- Isolation (peripheral nodes in a network),

- Bridge (members of a group that are linked to a subgroup of other networks),

- Intermediate (a node that links multiple groups without having a member of each group),

- Star (the node with the largest number of communication links) 
Table 4. The values of some structural indices in different network patterns

\begin{tabular}{|c|c|c|c|c|c|}
\hline $\begin{array}{l}\text { Network pattern } \\
\text { Structural indices }\end{array}$ & Star & Linear & Tree & Circular & Fully connected \\
\hline Mean difference & Zero or close to zero & Zero or close to zero & $\begin{array}{l}\text { One or close } \\
\text { to one }\end{array}$ & $\begin{array}{l}\text { One or close } \\
\text { to one }\end{array}$ & $\begin{array}{c}\text { One or close to } \\
\text { one }\end{array}$ \\
\hline Clustering coefficient & Zero or close to zero & & Zero & zero & $\begin{array}{l}\text { One or close to } \\
\text { one }\end{array}$ \\
\hline Density & $\begin{array}{l}\text { More density (close } \\
\text { to one) }\end{array}$ & $\begin{array}{l}\text { Lower density (close to } \\
\text { zero) }\end{array}$ & less & less & Less \\
\hline Degree centrality & $\begin{array}{l}\text { Centrality of one node } \\
\text { is more than other } \\
\text { nodes }\end{array}$ & $\begin{array}{l}\text { All nodes except for two } \\
\text { end node are equal }\end{array}$ & & $\begin{array}{l}\text { All nodes are } \\
\text { equal }\end{array}$ & All nodes are equal \\
\hline Betweenness centrality & $\begin{array}{l}\text { Centrality of one node } \\
\text { is more than other } \\
\text { nodes }\end{array}$ & Central node is more & & & All nodes are equal \\
\hline Closeness centrality & $\begin{array}{l}\text { Centrality of one node } \\
\text { is more than other } \\
\text { nodes }\end{array}$ & Central node is more & & & All nodes are equal \\
\hline
\end{tabular}

Where $\mathrm{Sv}$ is the weight degree of node $\mathrm{v}, \mathrm{Wvj}$ is the weight of the edges based on the annual traffic flow between two nodes, and (v) node is the neighbor node of $\mathrm{v}$ node (Wu \& Dong, 2015: 173).

Mean distance: The mean distance in the network is the mean number of edges along the shortest routes among all possible node pairs in the network. The lower mean distance in the network makes the transmission of information faster across the network (Garaei \& Siamaki, 2016). In each network of any kind of connected graph, there are links between those nodes, and the nodes are connected in pairs. This connection may be direct (via only one link from origin to destination) or indirect (via one route that contains at least one intermediate node). In any case, the shortest route between each pair of nodes in the network can be calculated using mathematical methods. The mean of these distances is one of the structural indices of networks and it is determined by the following formula (Bing Wang, 2006).

\section{$l=\frac{1}{1 / 2 \mathrm{n}(\mathrm{n}-1)} \sum_{\mathrm{i}>\mathrm{j}} \mathrm{d}_{\mathrm{ij}}$}

Where, dij is the number of edges for the shortest route from $\mathrm{i}$ to $\mathrm{j}$ and the diameter of a network is defined as the maximum value of all dijs. The mean route length is an index for the ease of travel in a network ( $\mathrm{J}$. Wang et al., 2011).

Clustering coefficient (separation of groups within the subgroups and network clusters):
The clustering index represents the ratio of the number of links around a node to the number of possible links in the whole network. It also takes a value between zero and one. The values close to one indicate the high rate of relationships with nodes of other clusters among the cluster nodes themselves. The values close to zero indicate that the node merely links other nodes (Garaei \& Siamaki, 2016). Grouping actors into one network is one of the most important concepts for examining the structure of a network. It allows us to know how an actor or organization behaves within a group as well as the behavior of the entire network. It also enables us to identify the weak and strong parts within a network by examining the number and severity of inter-group and intra-group communications. There are various methods for grouping actors within the network, such as the Ncliques and $\mathrm{K}$ - cores (1:51). Therefore, the clustering coefficient $(\mathrm{Ci})$ of a node is the ratio of the real edges $(\mathrm{Ej})$ among the nodes $(\mathrm{Ki})$ near it to the maximum possible edges (Ki (Ki-1) / 2) among them. Hence, it is written as follows:

$$
\mathrm{C}_{\mathrm{i}}=\frac{\mathrm{E}_{\mathrm{i}}}{\mathrm{K}_{\mathrm{i}}\left(\mathrm{K}_{\mathrm{i}}-1\right) / 2}
$$

It should be noted that the neighborhood of node i, except for the node $\mathrm{i}$ itself, includes all nodes directly connected to it. High values of $\mathrm{Ci}$ mean that the node has an intensive connection/communication system with its neighbors. In a fully connected network, $\mathrm{Ci}$ of all nodes takes the value one and $\mathrm{Ci}$ of nodes with $\mathrm{Ki}=1$ take the value zero. 
The clustering coefficient of the entire network $\mathrm{C}$ is the mean of all individual $\mathrm{Cis}$ and:

$\mathrm{C}=\frac{1}{\mathrm{n}} \sum_{\mathrm{vi} \in \mathrm{V}} \mathrm{C}_{\mathrm{i}}$

When the value of $\mathrm{C}$ is larger, it is more likely that the nodes reach each other at a short topological distance (such as communication or transportation) (Houston et al., 2004).

\section{Centrality}

The concept of centrality in the network was first developed by Bavelas (1948). Since then, several centrality criteria have been developed that have become vital concepts for understanding the structural characteristics of complex communication networks. In recent years, centrality coefficients have been used to analyze urban street networks (Wang et al., 2013). Thus, centrality (the effect of groups and subgroups on the network) has a broad meaning that is used to identify actors or communications within a network. The most important and applicable centralities are degree, closeness, betweenness, and eigenvector. Centrality measures the importance of a node based on its position in the network. For example, in a star network, the central node has the highest centrality and all other nodes have the least centrality. In fact, the star is the most concentrated type of graph. Different centrality criteria provide different aspects of an agent's position in the network, so selecting the right criterion depends on the specific application investigated (D. Konig \& Stefano, 2009: 104). Different criteria of centrality that are a combination of different aspects of the position of nodes in the network are introduced.

Degree centrality: It is the simplest type of centrality in which the value of the centrality of a point is obtained only by counting the number of its neighbors. When the degree of a point is higher, its access to resources will be greater and it is considered more central (Houston et al., 2004). In other words, in a network, some nodes (vertices) are more "important" than other nodes. The importance is often measured by some type of dynamic processes, such as social influence, but sometimes, it is generally defined structurally. Generally, it is better to measure the importance or centrality directly, perhaps by simulating dynamic processes and measuring the contributions of each vertex (Clauset, 2011: 18).

Therefore, to interpret this index, it is necessary to focus on the actors or nodes, considering their input and output. Accordingly, the nodes are divided into three groups of source (base) nodes, receiver nodes, and powerful nodes (Alistair. C. Ford et al., 2015: 124-149). In fact, the degree centrality of a node indicates the importance of that node in the network. The degree centrality of node i reflects its connection to the network and is defined in this way:

$$
\mathrm{C}_{\mathrm{D}}(\mathrm{i})=\sum_{\mathrm{j=1}}^{\mathrm{n}}\left(\mathrm{a}_{\mathrm{ij}}\right)
$$

If there is a direct link between node $\mathrm{i}$ and $\mathrm{j}$, aij $=1$; otherwise, its value will be zero. In the directional network, two criteria of inner and outer degrees are defined for degree centrality (J. Wang et al., 2011).

Closeness centrality: This centrality focuses on the distance of each node from other nodes in the network and ranks them based on closeness or accessibility. The point that is close to all points on average has the highest closeness centrality (Houston et al., 2004: 240). The closeness centrality reflects the availability of that particular node in the network. The closeness centrality of node $i$ is written in this way:

$\mathrm{C}_{\mathrm{C}}(\mathrm{i})=\frac{\mathrm{n}-1}{\sum_{\mathrm{v}_{\mathrm{i}} \in \mathrm{V} \neq \mathrm{j}} \mathrm{d}_{\mathrm{ij}}}$

In other words, the closeness of a node is the average inverse of the shortest distance of node $\mathrm{i}$ to all other nodes in a network. The larger value of this index indicates that it is easier to reach other nodes ( $\mathrm{J}$. Wang et al., 2011).

Betweenness centrality: This centrality is calculated based on the position of the nodes in the network and the shortest route between the pairs of other nodes, so the point has the highest betweenness centrality that has been located between many other pairs of routes and the communication routes of other points pass through it (Houston et al., 2004: 240). Also, when they are close to manufacturers and transporters, these nodes will tend to be more powerful and intermediary among other nodes (Alistair C. Ford et al., 2015: 124- 149). The betweenness centrality of node $i$ is defined as the percentage of all the shortest routes passing through that node and indicates its transferability, so:

$$
\mathrm{C}_{\mathrm{B}}(\mathrm{i})=\sum_{\mathrm{K} \neq \mathrm{i} \neq \mathrm{j} \in \mathrm{N}} \sigma_{\mathrm{kj}}(\mathrm{i}) / \sigma_{\mathrm{kj},}
$$


Where $\sigma \mathrm{kj}$ is the sum of the short routes between node $\mathrm{vk}$ and $\mathrm{vj}$, and $\sigma \mathrm{kj}$ (i) is the number of short routes passing through node vi. The node that creates the shortest route between other nodes has a higher betweenness centrality than other nodes (J. Wang et al., 2011).

Eigenvector centrality: The effect of a node is not only determined by the number of its neighbors, but also by the influence of its neighbors, as the effect of a mutual increase. One of the common centralities in which each node is supported by its neighbors is the eigenvector centrality algorithm that is used in non-directional networks. Even if one node is connected to only a few other nodes (with a low degree of centrality), these neighboring nodes may be important; as a result, the importance of the node increases, and its eigenvector centrality will also be high. In the eigenvector centrality, it is assumed that the effect of a node is determined not only by the number of its neighbors but also by the influence of each of the neighbors (degree of centrality of the neighbors). The centrality of a node is proportional to the sum of the centralities of the nodes connected to it. The importance of a node vi is represented by $\mathrm{xi}$, which is:

$\mathrm{X}_{\mathrm{i}}=\mathrm{c} \sum_{\mathrm{j}=1}^{\mathrm{n}}$ aijxj,
Its matrix form can be written as:

\section{$\overrightarrow{\mathrm{x}}=\mathrm{cA} \overrightarrow{\mathrm{x}}$}

Where $\mathrm{c}$ is a constant number. In general, $\mathrm{c}=1 / \lambda$ where $\lambda$ is the largest eigenvalue of A. The eigenvector centrality can be calculated using the power iteration method. At the beginning of the power iteration, the score for each node is considered to be 1 . Then, each node distributes its score evenly to the connected neighbors and receives new values repeated in each of iterations. This process is repeated until the node value reaches a stable state (Linyuan Lü et a1., 2016: 651-663). In general, this centrality seeks to find the central actors that have the least distance from the others. Accordingly, the point that has the most central neighbors will have the highest eigenvector centrality.

Houston et al. examined the degree centrality to assess the effect of major structural changes on communication and communication patterns (Houston et al., 2004: 240).

Given what was stated, the conceptual model of rural road network pattern analysis in rural areas exporting agricultural crops can be outlined in this way (Figure 1).

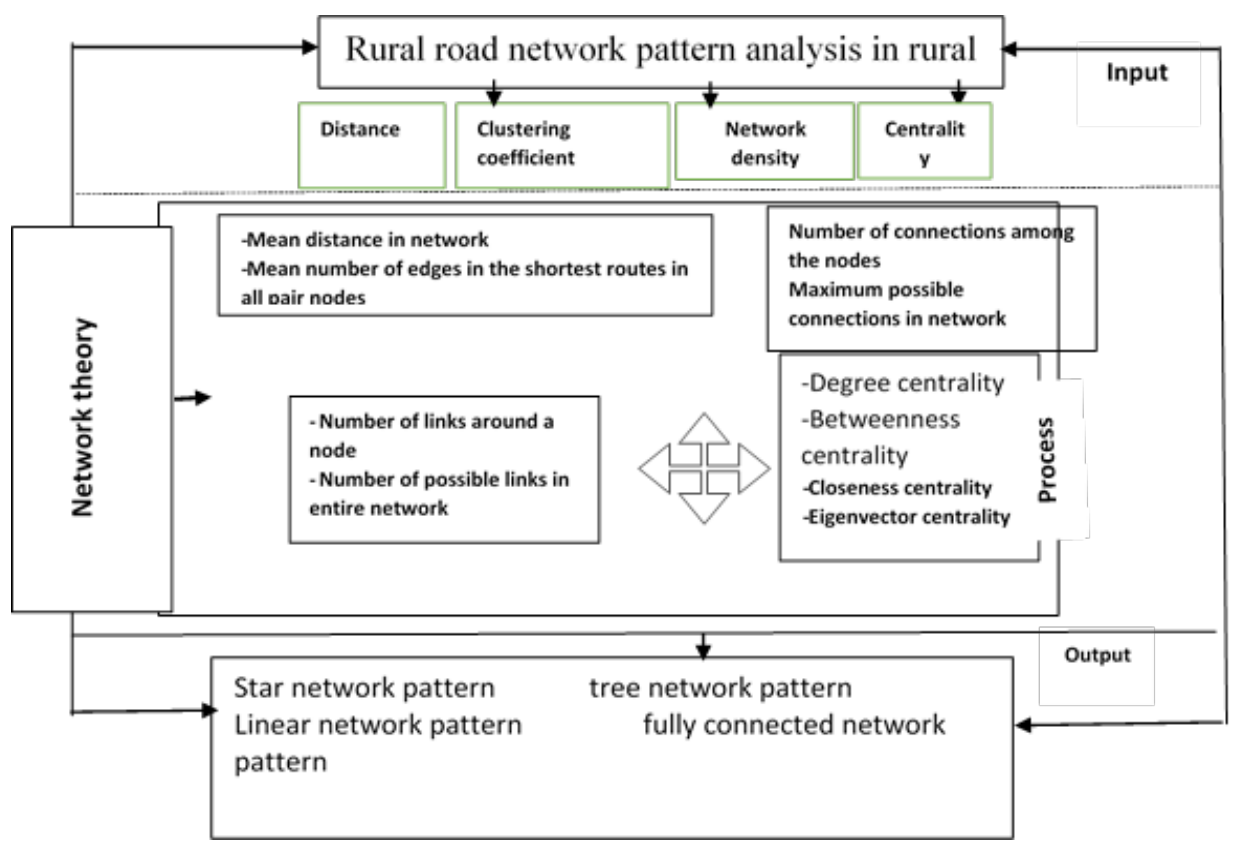

Figure 1. Conceptual model of research 


\section{Methodology}

Given the theoretical nature of the network, in its analysis, three steps are taken that are based on the relationships between the phenomena. The first step is to map and analyze the flow-relationship. In this method, the functional regions are determined based on the frequency, intensity, and direction of the real flows between the main centers and the surrounding centers. The second step is to map and analyze the geographical graph matrix that shows the existence or absence of a link between rural settlements through zero and one. The third step is to map the geographic networks proportional to the input data and to analyze the geographic output networks through network analysis software such as Ucinet, Gephi, and so on. Accordingly, the research method of this study is descriptive-analytical and it is based on the network analysis method. Library and field study methods were used for collecting data. In the field method, the amount of crop entered into the cold stores from each village was determined through in-person interviews with the owners of the cold stores. Then, using the network analysis method, the relationship between villages and the network pattern was examined. The diagraph of each of the relationships was also plotted using Ucinet software. Therefore, according to the previous studies conducted in the field of spatial structure analysis and based on the research literature, the indices of rural road network pattern analysis in the study area are presented in Table 5.

In this study, seven indices were studied for analyzing the spatial structure of the access road network. Four indices related to the characteristics of network nodes (villages and cold stores) and three indices related to the entire studied and analyzed network. The studied rural nodes are apple crop producing villages that send their crops through the road network to villages with agricultural crop cold stores.

\section{Study area}

In this study, 43 villages producing apple crop above the average were selected among 90 villages and four rural roads were selected among the routes (Table 6). Figure 2 and Figure 3 illustrate the location of the studied villages and roads.

Table 5. Studied variables and indices of the structural pattern of the road access network in the study area

\begin{tabular}{|c|c|c|c|}
\hline Variable & Indices & Indicators & Variables \\
\hline \multirow{7}{*}{ 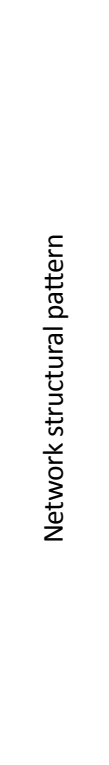 } & Degree centrality & $\begin{array}{l}\text { The sum of the inner degrees and the outer degrees of } \\
\text { the node }\end{array}$ & $\begin{array}{l}\text { inner degrees of the node } \\
\text { outer degrees of the node }\end{array}$ \\
\hline & $\begin{array}{l}\text { Betweenness } \\
\text { centrality }\end{array}$ & $\begin{array}{l}\text { The ratio of short routes passing through a node to the } \\
\text { sum of short routes between two nodes }\end{array}$ & $\begin{array}{l}\text { - Short routes passing through a node } \\
\text { - Sum of short routes between two } \\
\text { nodes }\end{array}$ \\
\hline & Closeness centrality & $\begin{array}{c}\text { Average inverse of the shortest distance of node i to all } \\
\text { other nodes }\end{array}$ & $\begin{array}{c}\text { The total number of nodes minus one } \\
\text { Shortest node distance to all network } \\
\text { nodes }\end{array}$ \\
\hline & $\begin{array}{l}\text { Eigenvector central- } \\
\text { ity }\end{array}$ & The number of node neighbors & The number of node neighbors \\
\hline & Density & $\begin{array}{l}\text { The ratio of the number of connections among the } \\
\text { nodes to the maximum possible network connections }\end{array}$ & $\begin{array}{l}\text { The number of connections among the } \\
\text { nodes } \\
\text { The maximum possible network connec- } \\
\text { tions }\end{array}$ \\
\hline & Cluster & $\begin{array}{c}\text { The ratio of the number of links around a node to the } \\
\text { number of possible links in entire network }\end{array}$ & $\begin{array}{c}\text { The number of links around a node } \\
\text { The number of possible links in entire } \\
\text { network }\end{array}$ \\
\hline & $\begin{array}{l}\text { Distance or esti- } \\
\text { mate }\end{array}$ & $\begin{array}{l}\text { The ratio of the mean distance in the network to the } \\
\text { mean number of edges along the shortest routes } \\
\text { among all possible node pairs in the network }\end{array}$ & $\begin{array}{l}\text {-Mean distance in the network } \\
\text { - Mean number of edges along the short- } \\
\text { est routes among all possible node pairs }\end{array}$ \\
\hline
\end{tabular}

Source: Authors using the literature of the research 


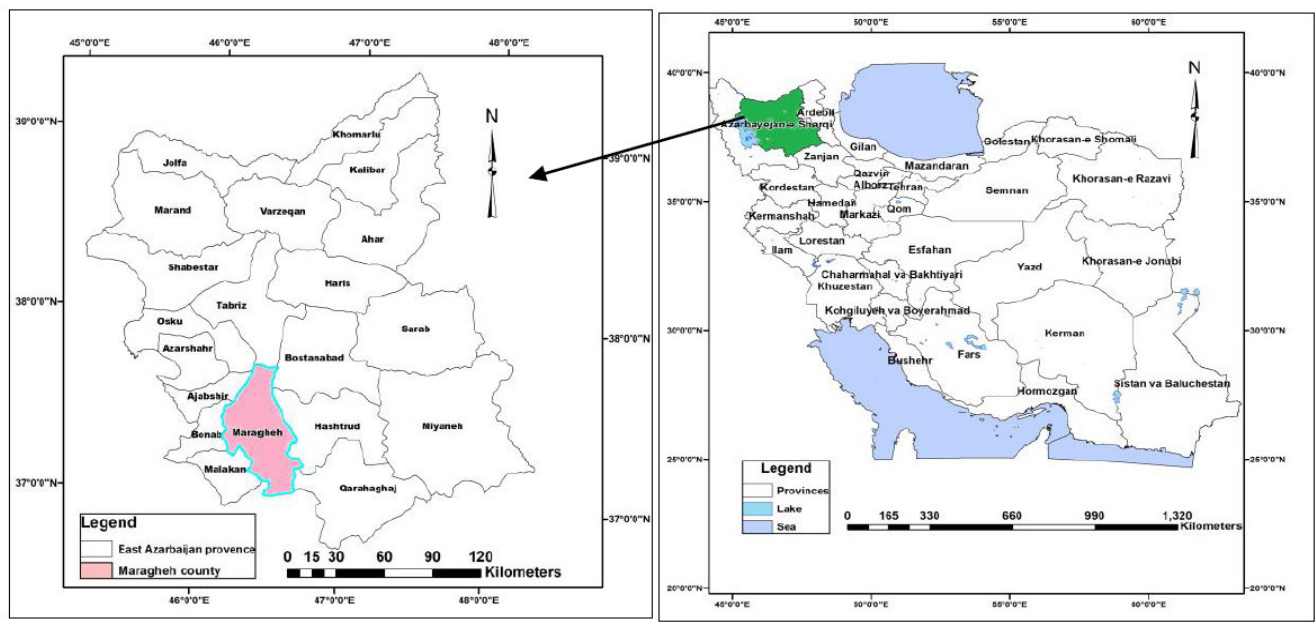

Figure 2. Location of the studied villages and roads

Table 6. Characteristics of the studied villages and areas under cultivation and yield of apple crop in 2018

\begin{tabular}{|c|c|c|c|c|c|c|c|}
\hline Row & City & Village & Total population & $\begin{array}{l}\text { Number of } \\
\text { households }\end{array}$ & $\begin{array}{l}\text { Number of } \\
\text { agricultural } \\
\text { workers }\end{array}$ & $\begin{array}{c}\text { Area under } \\
\text { cultivation / } \\
\text { hectare }\end{array}$ & $\begin{array}{l}\text { Average yield/ } \\
\text { tons }\end{array}$ \\
\hline 1 & Maragheh & Ahmadabad & 1207 & 310 & 234 & 75 & 45 \\
\hline 2 & Maragheh & Esfehanjiq & 844 & 219 & 241 & 330 & 31 \\
\hline 3 & Maragheh & Aghbolagh-e Alamdar & 9 & 4 & $*$ & 40 & 60 \\
\hline 4 & Maragheh & Aghajari & 563 & 154 & 170 & 500 & 35 \\
\hline 5 & Maragheh & Almachovan & 228 & 66 & 69 & 170.5 & 45 \\
\hline 6 & Maragheh & Behnag & 451 & 119 & 133 & 135 & 55 \\
\hline 7 & Maragheh & Tazeh Kand Aliabad & 365 & 101 & 119 & 134 & 55 \\
\hline 8 & Maragheh & Tazeh Kand Ghasemkhan & 365 & 101 & 119 & 134 & 55 \\
\hline 9 & Maragheh & Tazekand Sofla & 376 & 115 & 57 & 50 & 43 \\
\hline 10 & Maragheh & Chekan & 1120 & 302 & 168 & 140 & 55 \\
\hline 11 & Maragheh & Chekan Sofla & 576 & 147 & 133 & 220 & 5400 \\
\hline 12 & Maragheh & Chekan Olia & 688 & 181 & 64 & 70 & 1650 \\
\hline 13 & Maragheh & Chavan Bagh & 907 & 257 & 273 & 250 & 45 \\
\hline 14 & Maragheh & Cahavan Alamdar & 41 & 15 & $*$ & 30 & 50 \\
\hline 15 & Maragheh & Kharajoo & & & & 183 & 45 \\
\hline 16 & Maragheh & Khalifeh Kandi & 423 & 111 & 92 & 55 & 30 \\
\hline 17 & Maragheh & Dash atan & 1218 & 361 & 226 & 320 & 45 \\
\hline 18 & Maragheh & Davah Buyoni & 63 & 16 & $*$ & 40 & 55 \\
\hline 19 & Maragheh & Divrazm & 253 & 132 & 71 & 50 & 20 \\
\hline 20 & Maragheh & Sargize & 1266 & 344 & 378 & 190 & 25 \\
\hline 21 & Maragheh & Shalilvand & 1114 & 278 & 229 & 100 & 40 \\
\hline 22 & Maragheh & Sowmaeh-ye Sofla & 1509 & 382 & 242 & 343 & 8360 \\
\hline 23 & Maragheh & Sowmaeh-ye Olya & 726 & 165 & 109 & 100 & 2400 \\
\hline 24 & Maragheh & Alov Kandi & 22 & 7 & $*$ & 35 & 38 \\
\hline 25 & Maragheh & Aliabad & 375 & 100 & 117 & 130 & 55 \\
\hline
\end{tabular}


Table 6. Characteristics of the studied villages and areas under cultivation and yield of apple crop in 2018

\begin{tabular}{|c|c|c|c|c|c|c|c|}
\hline Row & City & Village & Total population & $\begin{array}{l}\text { Number of } \\
\text { households }\end{array}$ & $\begin{array}{l}\text { Number of } \\
\text { agricultural } \\
\text { workers }\end{array}$ & $\begin{array}{l}\text { Area under } \\
\text { cultivation / } \\
\text { hectare }\end{array}$ & $\begin{array}{l}\text { Average yield/ } \\
\text { tons }\end{array}$ \\
\hline 26 & Maragheh & Qaratlu & 981 & 300 & 308 & 120 & 75 \\
\hline 27 & Maragheh & Gartavol & 1935 & 509 & 360 & 65 & 73 \\
\hline 28 & Maragheh & Qayeh Belaghi & 567 & 149 & 189 & 350 & 33 \\
\hline 29 & Maragheh & Kamelabad & 626 & 172 & 159 & 300 & 47 \\
\hline 30 & Maragheh & Karajabad & 2220 & 610 & 568 & 104 & 55 \\
\hline 31 & Maragheh & Karam Javan & & & & 500 & 45 \\
\hline 32 & Maragheh & Kordeh Deh & 1436 & 412 & 408 & 125 & 75 \\
\hline 33 & Maragheh & Kahjuq & 1449 & 402 & 239 & 300 & 45 \\
\hline 34 & Maragheh & Kohlan & 434 & 133 & 128 & 100 & 48 \\
\hline 35 & Maragheh & Goshayesh & 185 & 56 & 51 & 135 & 33 \\
\hline 36 & Maragheh & Gol & 308 & 89 & 60 & 140 & 30 \\
\hline 37 & Maragheh & Gol Tappeh & 1059 & 313 & 227 & 180 & 20 \\
\hline 38 & Maragheh & Mardagh & 844 & 219 & 241 & 330 & 85 \\
\hline 39 & Maragheh & Moghanjiq & 1978 & 565 & 351 & 280 & 15 \\
\hline 40 & Maragheh & Meymunaq & 451 & 119 & 133 & 135 & 35 \\
\hline 41 & Maragheh & Heraq & 361 & 95 & 88 & 95 & 55 \\
\hline 42 & Maragheh & Yayshahr & 392 & 86 & 140 & 30 & 20 \\
\hline 43 & Maragheh & Yengejeh & 1756 & 491 & 317 & 274 & 77 \\
\hline
\end{tabular}

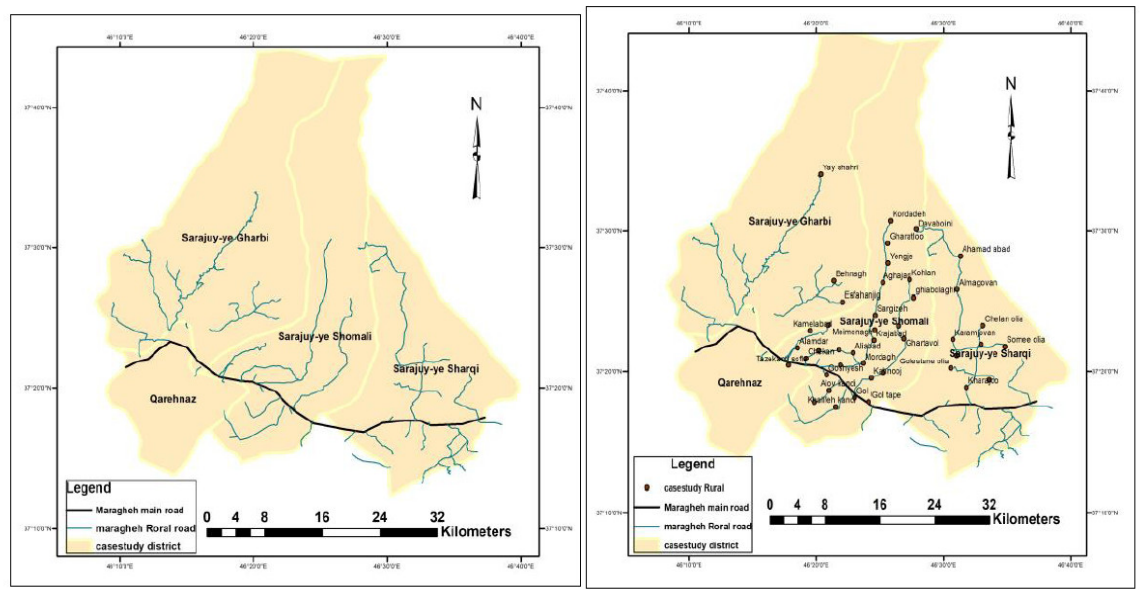

Figure 3. Geographical location map of the study villages and roads

At the next level, the statistics of the agricultural crop cold stores of Maragheh were obtained from the Agricultural Jihad of Maragheh, and 12 out of 34 cold stores were selected as active cold stores for the study. In the next step, the amount of apples entering each of the cold stores in each of the villages was determined through inperson interviews with the management of cold stores. In this study, the rate of apple production in each village and the amount of apples sent to each cold store was determined. Table 7 illustrates the apple crop in the study villages and the amount of apples sent to the cold stores in the destination village. 
Table 7. The apple production rate in the study villages and the number of apples sent to the cold store in the destination village

\begin{tabular}{|c|c|c|c|c|c|}
\hline Row & Destination village & $\begin{array}{l}\text { Village pro- } \\
\text { duction rate }\end{array}$ & $\begin{array}{l}\text { Sent to cold } \\
\text { storage }\end{array}$ & Cold storages & $\begin{array}{l}\text { Destination vil- } \\
\text { lage }\end{array}$ \\
\hline 1 & Ahmadabad & 1250 & 180 & Buran Sahand -180 & Gol \\
\hline 2 & Esfehanjiq & 600 & 25 & Taheri -25 & Gol \\
\hline 3 & Aghbolagh-e Alamdar & 600 & 170 & Buran Sahand -170 & Gol \\
\hline 4 & Aghajari & 8000 & 1911 & $\begin{array}{c}\text { Keshavarzan Sahand -250, Setareh Sahand } \\
-450 \text {, Sib Tala -115, Mazrae Sabz -96, } \\
\text { Bahmani -350, Memarzadeh } 650\end{array}$ & $\begin{array}{l}\text { Kharajoo- Alamdar- } \\
\text { Gol- Tazeh Kand } \\
\text { Sofla- Chekan }\end{array}$ \\
\hline 5 & Almachovan & 750 & 318 & $\begin{array}{c}\text { Keshavarzan Sahand -150, Buran Sahand } \\
168\end{array}$ & Kharajoo- Gol \\
\hline 6 & Behnag & 2000 & 200 & Mazrae Sabz 200 & Tazeh Kand Sofla \\
\hline 7 & Tazeh Kand Sofla & & & & \\
\hline 8 & Tazeh Kand Aliabad & 2500 & 40 & Mazrae Sabz -40 & Tazeh Kand Sofla \\
\hline 9 & Chekan & 2750 & 795 & $\begin{array}{c}\text { Sib Tala -50 Buran Sahand -200, Mazrae } \\
\text { Sabz -50, Miveh Sazakh } 45\end{array}$ & $\begin{array}{l}\text { Gol- Tazeh Kand } \\
\text { Sofla }\end{array}$ \\
\hline 10 & Chekan Sofla & 1000000 & 100 & Sib Tala -110 & Gol \\
\hline 11 & Chekan Olia & 62500 & 100 & Sib Tala -100 & Gol \\
\hline 12 & Chavan Bagh & 3000 & 1060 & $\begin{array}{l}\text { Mazrae Sabz -65, Bahmani -250, Sadaf } \\
\text {-160, Memarzadeh -550, Miveh Sazakh } 35\end{array}$ & $\begin{array}{l}\text { Tazeh Kand Sofla- } \\
\text { Chekan }\end{array}$ \\
\hline 13 & Cahavan Alamdar & 100 & 45 & Buran Sahand -45 & Gol \\
\hline 14 & Kharajoo & 750 & 300 & Taheri -300 & Gol \\
\hline 15 & Khalifeh Kandi & 30 & 25 & Buran Sahand -25 & Gol \\
\hline 16 & Dash atan & 5000 & 1130 & $\begin{array}{l}\text { Memarzadeh -700, Bahmani -300 Mazrae } \\
\text { Sabz }\end{array}$ & $\begin{array}{l}\text { Chekan- Tazeh Kand } \\
\text { Sofla }\end{array}$ \\
\hline 17 & Davah Buyoni & 500 & 50 & Buran Sahand 50 & Gol \\
\hline 18 & Divrazm & 240 & 150 & Buran Sahand -150 & Gol \\
\hline 19 & Sargize & 2250 & 1855 & $\begin{array}{l}\text { Setareh Sahand -460, Sib Tala -100, Maz- } \\
\text { rae Sabz - } 95 \text {, Bahmani -300, Memarzadeh } \\
\text {-550, Adlim Sahand } 350\end{array}$ & $\begin{array}{l}\text { Alamdar- Gol- Tazeh } \\
\text { Kand Sofla-Chekan- } \\
\text { Sargize }\end{array}$ \\
\hline 20 & Shalilvand & 1000 & 150 & Sadaf -150 & Tazeh Kand Sofla \\
\hline 21 & Sowmaeh-ye Sofla & 2250000 & 95 & Sib Tala -95 & Gol \\
\hline 22 & Sowmaeh-ye Olya & 160000 & 80 & Sib Tala -80 & Gol \\
\hline 23 & Alov Kandi & 105 & 30 & Buran Sahand -30 & Gol \\
\hline 24 & Aliabad & 2625 & 400 & $\begin{array}{c}\text { Mazrae Sabz }-50 \text {, Memarzadeh -300, Mive } \\
\text { Sazakh } 50\end{array}$ & $\begin{array}{l}\text { Chekan- Tazeh Kand } \\
\text { Sofla }\end{array}$ \\
\hline 25 & Qaratlu & 2100 & 1540 & $\begin{array}{l}\text { Sib Tala -160, Memarzadeh -550, Bahmani } \\
-330 \text {, Sard Sahand -350, Adlim Sahand } 150\end{array}$ & $\begin{array}{l}\text { Gol- Tazeh Kand } \\
\text { Sofla-Chekan- Kor- } \\
\text { deh Deh-Sargize }\end{array}$ \\
\hline 26 & Gartavol & 700 & 1230 & $\begin{array}{l}\text { Keshavarzan -250, Buran Sahand -300, } \\
\text { Taheri -350, Sib Tala -180, Sadaf } 150\end{array}$ & $\begin{array}{l}\text { Kharajoo- Gol- } \\
\text { Tazeh Kand Sofla }\end{array}$ \\
\hline 27 & Ghare Bolagh & & 285 & Bahmani -150, Sadaf -135 & Tazeh Kand Sofla \\
\hline 28 & Qayeh Belaghi & 3000 & 30 & Mazrae Sabz -30 & Tazeh Kand Sofla \\
\hline 29 & Kamelabad & 5000 & 140 & Mazrae Sabz -40, Sadaf 100 & Tazeh Kand Sofla \\
\hline 30 & Karajabad & 2350 & 1715 & $\begin{array}{c}\text { Setareh Sahand -350, Mazrae Sabz - } 50 \text {, } \\
\text { Sadaf -70, Memarzadeh -450, Bahman } \\
\text { Sahand 750, Mive Sazakh } 45\end{array}$ & $\begin{array}{l}\text { Alamdar- Tazeh } \\
\text { Kand Sofla-Chekan- } \\
\text { Sargize }\end{array}$ \\
\hline 31 & Karam Javan & 2500 & 1000 & $\begin{array}{l}\text { Buran Sahand }-250 \text {, Taheri }-300 \text {, Sib Tala } \\
-450\end{array}$ & Gol \\
\hline
\end{tabular}


Table 7. The apple production rate in the study villages and the number of apples sent to the cold store in the destination village

\begin{tabular}{|c|c|c|c|c|c|}
\hline Row & Destination village & $\begin{array}{l}\text { Village pro- } \\
\text { duction rate }\end{array}$ & $\begin{array}{l}\text { Sent to cold } \\
\text { storage }\end{array}$ & Cold storages & $\begin{array}{l}\text { Destination vil- } \\
\text { lage }\end{array}$ \\
\hline 32 & Kordeh Deh & 1950 & 1950 & $\begin{array}{c}\text { Sahand Keshavarzan -200, Buran Sahand } \\
\text {-300, Sard Sahand -700, Sib Tala -150, } \\
\text { Sadaf -150, Memarzadeh -450, Mive } \\
\text { Sazakh } 70\end{array}$ & $\begin{array}{l}\text { Kharajoo- Kordeh } \\
\text { Deh-Gol- Tazeh } \\
\text { Kand Sofla-Chekan }\end{array}$ \\
\hline 33 & Kahjuq & 200 & 650 & Taheri -400, Bahmani -250 & $\begin{array}{l}\text { Gol- Tazeh Kand } \\
\text { Sofla }\end{array}$ \\
\hline 34 & Kohlan & 1260 & 285 & Sib Tala -200, Sadaf -85 & $\begin{array}{l}\text { Gol- Tazeh Kand } \\
\text { Sofla }\end{array}$ \\
\hline 35 & Goshayesh & 150 & 33 & Sib Tala 33 & Gol \\
\hline 36 & Gol & 450 & 300 & Bahmani 300 & Tazeh Kand Sofla \\
\hline 37 & Gol Tappeh & 1400 & 200 & Bahmani 200 & Tazeh Kand Sofla \\
\hline 38 & Golestan-e Sofla & 2425 & 150 & Keshavarzan 150 & Kharajoo \\
\hline 39 & Golestan-e Olia & 3150 & 150 & Keshavarzan 150 & Kharajoo \\
\hline 40 & Mardagh & 3200 & 2350 & $\begin{array}{c}\text { Memarzadeh -550, Buran Sahand -250, } \\
\text { Setareh Sahand -650, Sib Tala -650, Bah- } \\
\text { man - } 250\end{array}$ & $\begin{array}{l}\text { Chekan-Gol- Alam- } \\
\text { dar- Tazeh Kand } \\
\text { Sofla }\end{array}$ \\
\hline 41 & Moghanjiq & 1500 & 820 & Taheri -350, Sib Tala -350, Sadaf -120 & $\begin{array}{l}\text { Gol- Tazeh Kand } \\
\text { Sofla }\end{array}$ \\
\hline 42 & Meymunaq & 2000 & 1230 & $\begin{array}{c}\text { Setareh Sahand -300, Mazrae Sabz -35, } \\
\text { Memarzadeh -500, Adlim Sahand -300, } \\
\text { Mive Sazakh } 95\end{array}$ & $\begin{array}{l}\text { Alamdar- Tazeh } \\
\text { Kand Sofla-Chekan- } \\
\text { Sargize- Tazeh Kand } \\
\text { Sofla }\end{array}$ \\
\hline 43 & Heraq & 2250 & 45 & Mive Sazakh -45 & Tazeh Kand Sofla \\
\hline 44 & Yayshahr & 600 & 50 & Sib Tala -50 & Gol \\
\hline 45 & Yengejeh & 3900 & 1600 & $\begin{array}{l}\text { Mazrae Sabz -100, Bahmani -300, Mme- } \\
\text { marzadeh -750, Adlim Sahand -200, Bah- } \\
\text { man Sahand } 250\end{array}$ & $\begin{array}{l}\text { Tazeh Kand Sofla- } \\
\text { Chekan- Sargize }\end{array}$ \\
\hline
\end{tabular}

\section{Findings}

As mentioned in the introduction section, the objective of this study is to analyze the access road network pattern in the form of apple crop transportation. The indices formulated in the theoretical foundations section to analyze the network pattern were analyzed in Ucinet 6 Software and the values of indices for each of the rural nodes and the entire network were determined. Figure 3 illustrates the inter-village road access network based on apple crop transportation to the study area. Table 6 also illustrates the measured indices for the access road network of the study area calculated using UCINE and Grade 6 software.

Types of centralities (degree, betweenness, closeness, eigenvector)

Figures 4, 6, 5, 7, and 8 illustrate the different types of centralities, including degree centrality, betweenness centrality, closeness centrality, and eigenvector centrality in the source and destination villages. The intensity of the flow of each village has been displayed by the thickness of the lines between the nodes. The size of the nodes is also proportional to the size of each type of centrality. Villages with higher centrality are represented by larger figures.

In the road access network, based on the transport of apple crops, the highest degree centrality belonged to Gol village, followed by Tazeh Kand Sofla, Chekan, Sargize, and Alamdar villages, respectively. Also, the intensity of crop flows from villages of Mardagh to Gol, from Mardagh to Chekan, from Aghajari to Chekan, from Dashatan to Chekan, and from Karam Javan to Gol was at a higher level (Figure 5). 


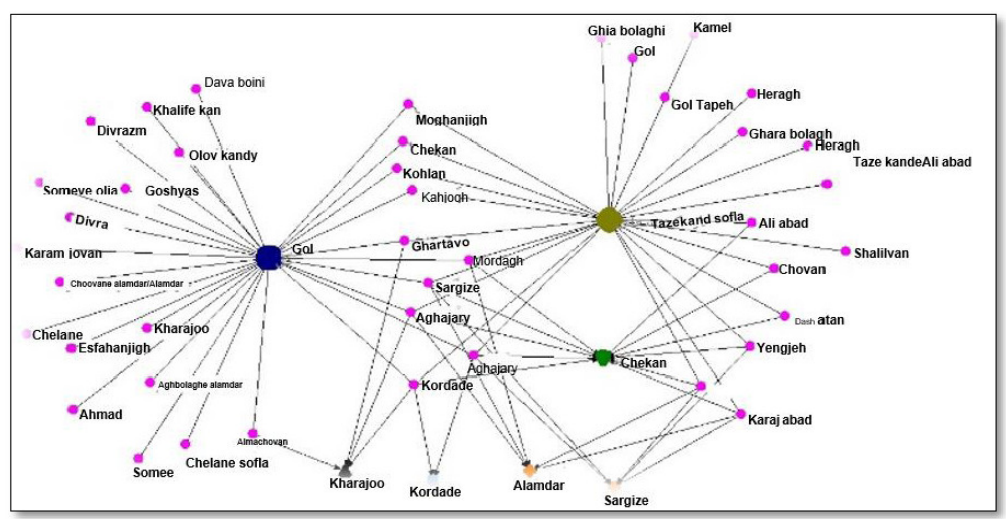

Figure 4. Graph of inter-village access road network based on apple crop transportation to the cold stores

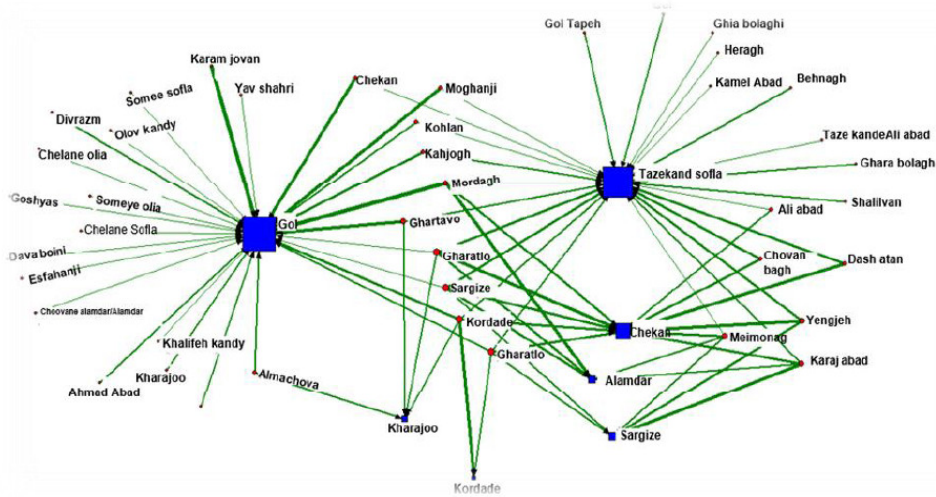

Figure 5. Flow and degree centrality of the road access network

The closeness centrality belonged to Gol village and Tazeh Kand Sofla village was ranked second and Sargize, Kordeh Deh, Aghajari, Qaratlu, Gartavol, Mardagh, Kahjuq, Kohlan, Chekan, and Moghanjiq villages were ranked third and the rest of the villages were placed at the next ranks (Figure 6).
The closeness centrality belonged to Gol village, Chekan and Sargize villages were ranked second, and Kordeh Deh village was ranked third (Figure 7). In fact, each of the villages with betweenness centrality is a communication way to other villages.

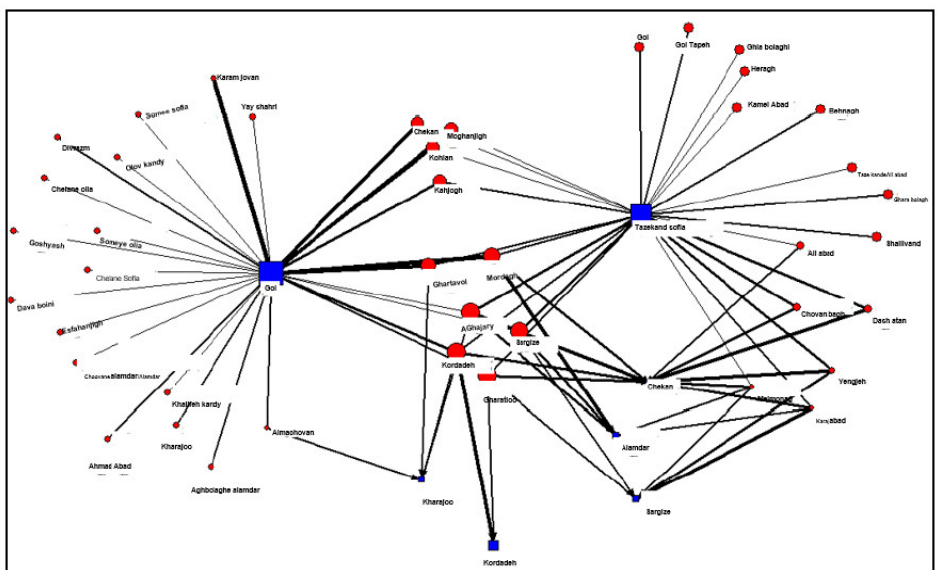

Figure 6. Flow and closeness centrality of the access road network 
The eigenvector centrality is the village that has more central neighbors. In this study, the eigenvector centrality was the Chekan village network, Gol village was ranked second, and Tazeh Kand Sofla, Mardaq, Sargize, and Kordeh Deh villages were ranked third. Also, Aghajari, Cahavan, Alamdar, Ghartavol, Meymunaq, Moghanjiq,
Yengejeh, Karam Javan, and Karaj Abad villages were ranked fourth and the rest of the villages had almost equal eigenvector centralities (Figure 8).

Finally, the values of the indices for each rural node and the entire network are presented in Table 8 .



Figure 7. Flow and betweenness centrality of the road access network

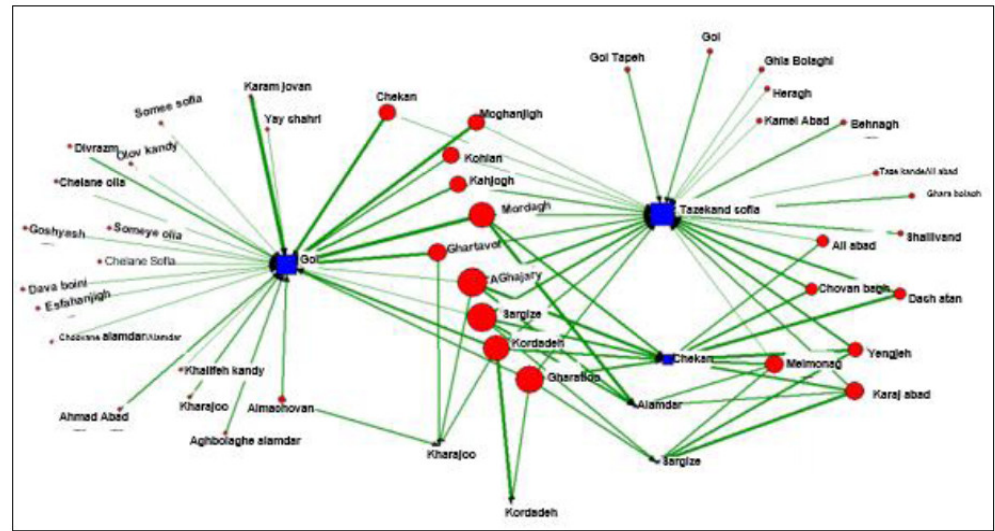

Figure 8. Flow and centrality of the eigenvector of the road access network for the apple crop

Table 8. Inter-village network access road indices based on apple crop transportation (nodes)

\begin{tabular}{|c|c|c|c|c|c|c|c|}
\hline & \multirow{2}{*}{$\begin{array}{l}\text { Indices } \\
\text { Villages }\end{array}$} & \multicolumn{2}{|c|}{ Degree centrality } & \multicolumn{2}{|c|}{ Closeness centrality } & \multirow{2}{*}{$\begin{array}{l}\text { Eigenvector } \\
\text { centrality }\end{array}$} & \multirow{2}{*}{$\begin{array}{l}\text { Between- } \\
\text { ness central- } \\
\text { ity }\end{array}$} \\
\hline & & Input degree & $\begin{array}{l}\text { Output } \\
\text { degree }\end{array}$ & $\begin{array}{c}\text { Input } \\
\text { closeness }\end{array}$ & $\begin{array}{l}\text { Output close- } \\
\text { ness }\end{array}$ & & \\
\hline 1 & Ahmadabad & 0.000 & 0.429 & 2.438 & 2.326 & 0.025 & 0.000 \\
\hline 2 & Esfehanjiq & 0.000 & 0.06 & 2.438 & 2.326 & 0.003 & 0.000 \\
\hline 3 & Aghbolagh-e Alamdar & 0.000 & 0.405 & 2.438 & 2.326 & 0.023 & 0.000 \\
\hline 4 & Aghajari & 0.000 & 4.55 & 2.632 & 2.326 & 0.193 & 0.000 \\
\hline 5 & Almachovan & 0.000 & 0.757 & 2.499 & 2.326 & 0.027 & 0.000 \\
\hline 6 & Behnag & 0.000 & 0.476 & 2.381 & 2.326 & 0.019 & 0.000 \\
\hline 7 & Tazeh Kand Aliabad & 12.967 & 0.000 & 2.326 & 71.186 & 0.29 & 0.000 \\
\hline 8 & Tazeh Kand Ghasemkhan & 0.000 & 0.095 & 2.381 & 2.326 & 0.004 & 0.000 \\
\hline
\end{tabular}


Table 8. Inter-village network access road indices based on apple crop transportation (nodes)

\begin{tabular}{|c|c|c|c|c|c|c|c|}
\hline & \multirow{2}{*}{$\begin{array}{l}\text { Indices } \\
\text { Villages }\end{array}$} & \multicolumn{2}{|c|}{ Degree centrality } & \multicolumn{2}{|c|}{ Closeness centrality } & \multirow{2}{*}{$\begin{array}{c}\text { Eigenvector } \\
\text { centrality }\end{array}$} & \multirow{2}{*}{$\begin{array}{l}\text { Betweenness } \\
\text { centrality }\end{array}$} \\
\hline & & Input degree & $\begin{array}{l}\text { Output } \\
\text { degree }\end{array}$ & $\begin{array}{c}\text { Input } \\
\text { closeness }\end{array}$ & $\begin{array}{l}\text { Output close- } \\
\text { ness }\end{array}$ & & \\
\hline 9 & Tazah Kand Sofla & 4.286 & 1.845 & 2.439 & 3.125 & 0.476 & 4.167 \\
\hline 10 & Chekan & 0.000 & 0.238 & 2.438 & 2.326 & 0.014 & 0.00 \\
\hline 11 & Chekan Sofla & 0.000 & 0.221 & 2.438 & 2.326 & 0.014 & 0.00 \\
\hline 12 & Chekan Olia & 0.000 & 2.524 & 2.499 & 2.326 & 0.135 & 0.00 \\
\hline 13 & Chavan Bagh & 5.262 & 0.107 & 2.438 & 2.774 & 0.171 & 0.667 \\
\hline 14 & Cahavan Alamdar & 2.024 & 0.714 & 2.438 & 2.630 & 0.085 & 0.00 \\
\hline 15 & Kharajoo & 0.000 & 0.060 & 2.438 & 2.326 & 0.003 & 0.000 \\
\hline 16 & Khalifeh Kandi & 0.000 & 2.69 & 2.499 & 2.326 & 0.151 & 0.00 \\
\hline 17 & Dash atan & 0.000 & 0.119 & 2.438 & 2.326 & 0.007 & 0.00 \\
\hline 18 & Davah Buyoni & 0.000 & 0.357 & 2.438 & 2.326 & 0.021 & 0.00 \\
\hline 19 & Divrazm & 3.929 & 3.583 & 2.564 & 2.564 & 0.293 & 3.167 \\
\hline 20 & Sargize & 0.000 & 0.357 & 2.381 & 2.381 & 0.014 & 0.00 \\
\hline 21 & Shalilvand & 0.000 & 0.226 & 2.438 & 2.326 & 0.013 & 0.00 \\
\hline 22 & Sowmaeh-ye Sofla & 0.000 & 0.19 & 2.438 & 2.326 & 0.011 & 0.00 \\
\hline 23 & Sowmaeh-ye Olya & 0.000 & 0.071 & 2.438 & 2.326 & 0.004 & 0.00 \\
\hline 24 & Alov Kandi & 0.000 & 0.952 & 2.499 & 2.326 & 0.057 & 0.00 \\
\hline 25 & Aliabad & 0.000 & 3.667 & 2.774 & 2.326 & 0.181 & 0.00 \\
\hline 26 & Qaratlu & 0.000 & 2.929 & 2.500 & 2.326 & 0.135 & 0.00 \\
\hline 27 & Gartavol & 0.000 & 0.679 & 2.381 & 2.326 & 0.027 & 0.00 \\
\hline 28 & Qayeh Belaghi & 0.000 & 0.071 & 2.381 & 2.326 & 0.003 & 0.00 \\
\hline 29 & Kamelabad & 0.000 & 0.333 & 2.381 & 2.326 & 0.013 & 0.00 \\
\hline 30 & Karajabad & 0.000 & 4.083 & 2.630 & 2.326 & 0.178 & 0.00 \\
\hline 31 & Karam Javan & 0.000 & 2.381 & 2.438 & 2.326 & 0.137 & 0.00 \\
\hline 32 & Kordeh Deh & 0.833 & 3.143 & 2.564 & 2.381 & 0.233 & 1.00 \\
\hline 33 & Kahjuq & 0.000 & 1.548 & 2.439 & 2.326 & 0.079 & 0.00 \\
\hline 34 & Kohlan & 0.000 & 0.679 & 2.439 & 2.326 & 0.036 & 0.00 \\
\hline 35 & Goshayesh & 0.000 & 0.079 & 2.438 & 2.326 & 0.005 & 0.00 \\
\hline 36 & Gol & 17.038 & 0.714 & 2.381 & 9.859 & 0.417 & 17.00 \\
\hline 37 & Gol Tappeh & 0.000 & 0.476 & 2.381 & 2.326 & 0.019 & 0.00 \\
\hline 38 & Mardagh & 0.000 & 5.595 & 2.564 & 2.326 & 0.27 & 0.00 \\
\hline 39 & Moghanjiq & 0.000 & 1.952 & 2.439 & 2.326 & 0.107 & 0.00 \\
\hline 40 & Meymunaq & 0.000 & 2.929 & 2.63 & 2.326 & 0.137 & 0.00 \\
\hline 41 & Heraq & 0.000 & 0.107 & 2.381 & 2.326 & 0.004 & 0.00 \\
\hline 42 & Yayshahr & 0.000 & 0.119 & 2.438 & 2.326 & 0.007 & 0.00 \\
\hline \multirow[t]{3}{*}{43} & Yengejeh & 0.000 & 3.81 & 2.628 & 2.326 & 0.199 & 0.000 \\
\hline & Mean & 1.310 & 1.310 & 2.326 & 4.145 & & 0.605 \\
\hline & Sum & 56.338 & 56.338 & 2.774 & 178.186 & & 26.00 \\
\hline 1 & $\begin{array}{l}\text { Network concentration } \\
\text { degree }\end{array}$ & \multicolumn{6}{|c|}{$0.97 \%$} \\
\hline 2 & Network density & \multicolumn{6}{|c|}{0.043} \\
\hline 3 & Mean distance & \multicolumn{6}{|c|}{0.05} \\
\hline 4 & Clustering coefficient & \multicolumn{6}{|c|}{0.447} \\
\hline
\end{tabular}


In the third step, the values calculated through software were matched with values of indices studied in each of the major network patterns concerning the structural indices of rural nodes (degree centrality, betweenness centrality, closeness centrality, and eigenvector centrality) and network (mean distance, network density, clustering coefficient). Finally, the road access network pattern based on apple crop transportation in the villages of the study area was identified:

Based on Table 1, the value of each of the network indices (mean distance, network density, clustering coefficient) in the star network pattern was equal or close to zero, and this value in the other three patterns was equal or close to 1 . Regarding network density index, its value in the star pattern was close to zero. By comparing the values of each of the three indices of the road access network, it can be stated that the pattern of the road access network in the study area is closer to the star pattern. Concerning structural indices of network nodes, in the star pattern (Table 4), the degree centrality of one node was higher than other nodes. In the studied network, the degree centrality of Chakan village was higher than that of other villages, and in the betweenness centrality index, Gol village had more centrality than other villages. Also, in the eigenvector centrality index, Chekan village had more centrality compared to other villages, and in the clos eness centrality, Tazeh Kand Sofla village had more centrality than other nodes. Therefore, concerning structural indices of the nodes, the road access network pattern in the studied villages was close to star pattern.

\section{Discussion}

Given the effect of the road network pattern on the ease of access and communication of rural areas with each other and the distance and cost of villagers' access to services, especially services related to the type of rural productions such as warehouses and cold stores of agricultural crops, this study was conducted to analyze the road network access structure pattern based on the transportation of agricultural crops to the villages with cold stores.

Regarding the differentiation of the present study with previous studies in Iran, it can be said that few studies have been done on network analysis as well as roads (the main roads for risk assessment) in the country, but no study has investigated the topological structure and communication pattern of the rural road network. In some studies in the field of rural road, only a few studies have focused on the role of the road in rural development and, as mentioned, the topological structure of the rural road network has not been analyzed and therefore, the present study is warranted. It can help enrich the literature of the subject and provide guidance for future studies. Comparing the findings of the study with those of other studies, the present study has used the studies of researchers such as Houston et al. (2004), J.W. et al., (2011), D. Konig $\&$ Stefano (2009), to analyze the indices and has been in line with the above studies. But in terms of introducing the final (stellar) pattern, it is different from their works.

Based on the analytical findings of the study, the rural road structural pattern in the study area was the star pattern. As villages nodes have centrality degree and high power in the network in the vicinity of the main Maragheh-Hashtrood road, the road connected to it has high technical standards compared to other roads, so most of the villagers send their apple crops to cold stores of this village, resulting in high concentration in these villages and making the network pattern close to star pattern. It also increases the distance and cost of access to distant villages and results in poor communication among the villages. Therefore, it is recommended to provide a link among the villages through clustering to facilitate the access of villagers to the cold stores and save their cost, time, and distance.

\section{Acknowledgements}

This research did not receive any specific grant from funding agencies in the public, commercial, or not-forprofit sectors.

\section{Conflict of Interest}

The authors declared no conflicts of interest.

\section{References}

Agricultural Jihad of Maragheh, Statistic Report, (2017).

Alis tair C. Ford, S. L. B., Richard J. Dawson, Philip J. (2015) Trans port Accessibility Analysis Using GIS: Assessing Sustainable Transport in London. ISPRS International Journal of Geo-Information, 4, 124-149.

Asgharpur, M., Hashemi; S. (2005). [Designing the Mathematical Model of Transportation Network of the Post Office of the Islamic Republic of Iran9persian)]. Moderes of Humanity sciences, $42,1-22$

Azarb ad, N. (2010). [Analysis of the settlement network with an emphasis on demographic trends in Firoozkooh city(persian)]. Human Geography Research, 74, 75-89. 
Badri; A., Akbarian Ronizi S. R. (2008). [Analysis of FunctionalService Relationships of Human Settlements Using Network Analysis Method: Roniz's Section (persian)]. Moderes of Humanity sciences, 12(2), 28-21.

Blyde J. (2010). paving the road to export the trade impacts of domestic transportation costs and road quality, Inter-American Development Bank.

Bono, F., Gutiérrez, E. (2011). A network-based analysis of the impact of structural damage on urban accessibility following a disaster: the case of the seismically damaged Port Au Prince and Carrefour urban road networks. Journal of Transport Geography, 19, 1443-1455.

Clauset, A. (2011). inference, models and simulation for complex systems Paper presented at the csci.

D. K onig, Stefano Battiston. (2009). "From Graph Theory to Models of Economic." Lecture Notes in Economics and Mathematical Systems 163, 104.

Davide, E. (1996). Tree-Weighted Neighbors and Geometric k Smallest Spanning Trees. Int. J. Comp. Geom. \& Appl, 4, 229238.

Gar ayi, E., Siamaki, S. (2016). [performance Evaluation of researc hers, universities and research institutes in the field of Ir anian engineering education; Based on social network analysis indicators(persian)]. Iran engineering education(70), 118-199.

Hama ina, R. (2011). A structural analysis of street networks to determine the characteristics of urban fabric, ICC 2011 25th International Cartographic Conference, Jul 2011, Paris, France. ffhal-01347325f

Houston M., H. M., Moorman Ch., Peter H. R. . (2004). a network persp ective on marketing strategy performance. Retrieved from canbridge:

J. Wang, H. M., Fahui W., Fengjun J. (2011). Exploring the network structure and nodal centrality of China's air transport network: A complex network approach. Journal of Transport Geography, 19, 712-721.

Katz, N., Lazer, D., Arrow, H., Contractor, N. (2004). network theory and small groups. small group research, 35(3), 307-332.

Liny uan Lü, D. C., Xiao-Long R., Qian-Ming Z., Yi-Cheng Z., Tao Z. (2016). Vital nodes identification in complex networks. Physics Reports, 650 651-663.

Lunenburg, F. C. (2011). network patterns and analysis: underused sources to improve communication effectiveness. national forum of educational administration and supervision journal, 28(4), 825-846.

Oftadeh,J. (2016). [Analysis of Social Networks. Tehran(persian)]: Sanieh.

Pandya, K. (2013). Network Structure or Topology, International Journal of Advance Research in Computer Science and Management Studies, Volume 1, Issue 2, 21-27.

Ramezani A., M. a. (2015). [Analysis of Social Networks Whit UCINET Software Tehran(persian)]: jameeshanasan.

Rezv ani, M. R., M. H., Hadi, K. (2014). Network Analysis in Tourism. Tehran: Mahkameh (Persian).
Snarskii, A ., Zorinets, D. I., Lande, D.V. (2016). "Conjectural" links in complex networks. Physica A, 462, 266-273.

S. Boccaletti, L. V., Moreno Y., Chavez M., Hwang D.-U. (2006). Complex networks: Structure and dynamics. Physics Reports, $424,275-308$.

Sadeghi, H., Safari, N. (2013). [Optimum Foil Oil Transport Network. Tarbiat Modarres University(persian)], 9(39), 105-131.

Sadeghlo, T. (2012). [Presentation Marketing Network Patern for Milk In Rurals area Case study: Zanjan Province (phd) (persian)], Tehran.

Vaughan, R. (1987). Urban spatial traffic patterns, London, England.

Wang, X., Wu, X., Abdel-Aty, M., Tremont, P.J. (2013). Investigation of road network features and safety performance, Accident Analysis and Prevention (56) 22-31.

Wu, W., Dong, Z. (2015). Exploring the Geography of China's Airport Networks: A Hybrid Complex-Network Approach. Paper presented at the SERC DISCUSSION, China, March 2015.

Xie, F., Levinson, D. (2007). Measuring the Structure of Road Networks, Geographical Analysis (39)336-356. 
